The resurgence of the Selk'nam. Dynamics of ethnoheterogenesis, ethnicity, and legal recognition in the Tierra del Fuego

Runas. Journal of Education and Culture 


\title{
The resurgence of the Selk'nam. Dynamics of ethnoheterogenesis, ethnicity, and legal recognition in the Tierra del Fuego
}

El resurgimiento de los Selk’nam. Dinámicas de etnoheterogénesis, etnicidad y reconocimiento legal en la Tierra del Fuego

Javier Lastra-Bravo

Gottfried Wilhelm Leibniz Universitat Hannover - Germany

Hannover, Germany

j.lastra.bravo@ish.uni-hannover.de

\begin{abstract}
This article has two central objectives, on the one hand, to analyze the process by which the Selk'nam population was declared extinct on the island of Tierra del Fuego, putting special emphasis on the process of colonization and the consequences this brought, especially the process of assimilation and ethnocide. Subsequently, a theoretical review is made of the concepts of ethnicity and ethnogenesis as processes through which the resurgence of groups of individuals who currently recognize themselves as members of the indigenous Selk'nam group can be explained. In this sense, the concept of Ethnoheterogenesis is linked as a model through which the current processes of self-recognition of individuals with ethnic groups can be explained. To conclude the article focuses the discussion on recognizing those cultural aspects present today, the action of ethnic groups, and the need for legal and symbolic recognition of the current existence of Selk'nam ethnic groups.
\end{abstract}

Keywords: Ethnogenesis; Ethnicity; Ethnoheterogenesis; Indigenous Peoples; Selk’nam

\section{RESUMEN}

Este artículo tiene dos objetivos centrales, por una parte, analizar el proceso mediante el cual se declaró la extinción de la población selk’nam en la isla de Tierra del Fuego, poniendo énfasis al proceso de colonización y las consecuencias que trajo esto, especialmente el proceso de asimilación y etnocidio. Posteriormente, se hace una revisión teórica sobre los conceptos de etnicidad y etnogénesis como procesos mediante los cual se puede explicar el resurgimiento de grupos de individuos que se autorreconocen actualmente como miembros del grupo indígena selk'nam. En ese sentido, se vincula el concepto de Ethnoheterogénesis como un modelo mediante el cual se puede explicar los procesos actuales de autorreconocimiento de individuos con grupos étnicos. Para finalizar, se centra la discusión en reconocer aquellos aspectos culturales presentes en la actualidad, la acción de colectividades etnopolíticas y la necesidad de un reconocimiento jurídico y simbólico de la existencia actual de grupos étnicos selk'nam.

Palabras claves: Etnogénesis; Etnicidad; Ethnoheterogénesis; Pueblos indigenas; Selk’nam 


\section{Introduction}

In 1973 the scientific discourse determined that the Selk'nam in Tierra del Fuego were extinct, the ancient inhabitants of that Austral territory had officially disappeared. However, in the past decades, several individuals began to group and identified themselves as belonging to the Selk'nam, thus resuming the culture of this group in the extreme south of the American continent.

The re-emergence of indigenous groups that were considered extinct, acquires importance today in relation to the necessary recognition by post-colonial states in Latin America of those indigenous groups that were forcibly assimilated. In this way, it is a current phenomenon that allows the expansion of Latin American democracies by recognizing the existence of different groups that have been invisibilized through history.

This is the case of the Selknam, who were considered extinct and are actually developing a political process in the search for recognition as a living indigenous group.

The loss, extinction, and emergence of indigenous groups is a global phenomenon and as such is a fact that has attracted the attention of researchers in recent decades (Barth, 1976; Lorandi \& Rio, 1992; Boccara, 1999; Bartolome, 2003; Gabbert, 2007; 2013; Voss, 2008; Luna, 2014; Mantel, 2017). This is due to a paradigm shift in the understanding of indigenous groups and processes that have been taking place in Latin America since the 1980s to the recognition of indigenous groups and the multiethnic character of nations.

This article will specifically study the situation of the Selk'nam, who have been declared extinct by traditional historiography. However, they are currently undergoing a process of visibilization, "resurgence" and recognition. The central hypothesis holds that the "resurgence" of the Selk'nam indigenous group is not determined by biological factors, but must be understood based on processes of self-identification, association, and cultural differentiation such as the process of Ethnoheterogenesis. In this sense, the contribution of this article is to propose another way of understanding and conceptualizing the emergence of indigenous groups through the concept of ethnicity and ethnoheterogenesis as analytical categories.

This article is the result of a documentary and theoretical analysis of the concepts of ethnicity and ethnogenesis, as those processes through which it is possible to analyze the resurgence of indigenous groups previously considered extinct, for example, the Selk'nam. The bibliographic research thus provides a frame of reference for the analysis and interpretation of empirical sociocultural phenomena such as the one mentioned above.

In this way, a historiographic review of the situation of the Selknam groups in Tierra del Fuego was carried out in the first place, paying attention to the processes of forced assimilation in the area. Subsequently, a theoretical review is made on the concepts of ethnicity, ethnogenesis and ethnoheterogenesis that allow being analytical references to study the case of ethoheterogenesis of the Selkanm and their social and cultural claims to the States of Chile and Argentina.

It is necessary to mention that this research is articulated to the process that is developing the Selknam groups in Chile in the search for their recognition as indigenous groups in the nation. Therefore, the interest of this article arises from the relevance of contributing from a scientific perspective to the debate for the recognition of indigenous groups in the postcolonial contexts of Latin American States. 


\section{Selk'nam, the inhabitants of Tierra del Fuego}

The Selk'nam, are the Amerindian inhabitants who lived some ten thousand years ago on the Isla Grande de Tierra del Fuego (Laming-Emperaire, 1968, pp. 77-100; Massone, Jackson, \& Prieto, 1993, p. 26), in the southernmost part of the American continent, which today corresponds to the territories of Chile and Argentina. These indigenous groups were characterized by being nomadic, traveling the vast island hunting especially guanacos (Lama guanicoe), taking advantage of their meat, skins, and tendons, with which they made their clothing, as well as their dwellings and tools. In addition to hunting, they also gathered different types of food. Coastal activities were also of great importance, such as hunting sea lions, whales stranded on the coast and fish (Chapman, 2008, p. 24).

The Selk'nam had an organizational conception of the territory, where each extended family was assigned a Haruwen (territory) in which they could move, with established limits known by the other families (Gusinde 1920a; 1920b; 1922; 1924; 1951). Similarly, the Selk'nam had a complex social structure (Chapman, 1973; 2008), with differentiated roles in the tribe (Gusinde, 1982).

The first historical records date back to 1520, when Hernando de Magallanes traveled the maritime passage of the southern tip of the American continent. In this record, the chronicler noted the presence of several bonfires on the island, which is why it was called Land of Fire (Tierra del Fuego). Later, in 1580, Pedro Sarmiento de Gamboa went to the Patagonian channels and the Strait of Magellan to learn about its geography and its inhabitants, thus generating the first contact between Europeans and Selk'nam.

\section{Occupation and colonization of Tierra del Fuego}

The contacts were maintained sporadically between navigators, hapless castaways and the original natives of the island. Until 1880, when the systematic occupation of the island began as a result of the discovery of gold in the Cordón Baquedano and the installation of cattle companies with English capital. At this time, it is estimated that the Selk'nam population was around 3,500 to 4,000 people (Chapman, 2008, p. 22). The occupation of the territory was sponsored both by the Chilean state in 1880 and by Argentina a few years later in 1886 (Chapman, 2008, p. 24).

An example of the cattle concessions is the Werhahn and Company, which in 1883 was granted a lease of 123,000 hectares on the Isla Grande of Tierra del Fuego, with the objective of implementing a cattle industry. Due to the great profitability of this company, in 1890, 1,009,000 hectares were given to José Nogueira. This demonstrates the consolidation of the large estates on the island and the sheep economy in Magallanes. These extensive areas of land were used by the colonizers in the establishment of a strong sheep farming industry linked to the English textile industry (Coronato, 2010, p. 26), which brought violent effects to the environment, the biodiversity of the area and the indigenous groups that lived there (Harambour, 2016, p. 8).

Thus, during the last decades of the 19th century and the first decade of the 2oth century, the Selk'nam, the original inhabitants of the island, were decimated and attacked by foreigners and settlers who came in search of riches. Many died as a result of diseases and epidemics, others were shipped to the European continent, exhibited in human zoos and others were hunted by professional killers, the "Indian hunters", who were hired by creoles and British landowners. Historical chronicles detail some practices to murder the Selk'nam such as banquets offered to the natives that culminated with rifle discharges, sport hunts of men and women in the Fuegian 
forests, poisoned beached whales and deliberately infected plagues (Bartolome, 2003, p. 177). It is necessary to mention that during the 19th and 2oth centuries it became popular to pay for the presentation of testicles, ears and breasts as a means of proof for a murdered Selk'nam.

The colonization process followed the parameters already established in other processes, such as the Occupation of Araucania in Chile and the Conquest of the Desert in Argentina. In other words, a racist-colonial ideology was established, based on social Darwinism, where the model to follow was based on European immigration, the presence of "whites" and where the indigenous people were considered archaic, dispensable and an obstacle to the progress of the region (Bartolomé, 2003, pp. 167-168). For this purpose, military posts were established in the territory to achieve the triple objective that the governments aspired to: "the civilization of the Indians, colonization of the territory and effective protection of people and goods for the peaceful development of the industries and companies stationed in Patagonia" (Instituto de Estudios Indígenas / Universidad de la Frontera, 2003, p. 349). About this process, the governor of Magallanes, Manuel Señoret, points out in his memoirs:

It is well known the power of assimilation of customs in savage peoples by the sight of other habits. If in Dawson Island there were some tens of Chilean families with their children, dedicated to the cultivation of the land, to the dairy industry and to the thousand attentions of the home, and the Indians surrounded them seeing at every moment that activity of the civilized family to provide their daily sustenance and greater comforts, it would serve them at the same time that of valuable school, of distraction. They would soon mix with these families, they would be occupied in this or that domestic work and in a very short time they would change their way of being and would understand in a practical way the advantages of civilized life] (Señoret, 1896, p. 32).

Colonization and the loss of the territory made obtaining food and hunting guanacos an increasingly difficult task for the Selk'nam. Because of this, sheep-stealing became a survival task, causing the ranchers to adopt an even more aggressive and extermination policy towards the native population of the island. This only diminished when the Salesian missionaries built indigenous reserves in other areas of the island, in San Rafael (1889) on Dawson Island and La Candelaria (1893) at the mouth of the Rio Grande.

Parallel to the assimilation process, the process of evangelization took place in the indigenous reserves managed by the Salesian missionaries, where the surviving Selk'nam were taught Catholic knowledge and Western education:

\footnotetext{
At Dawson the savages are initiated into the Spanish language by the reading in chorus of the books of Nunez and the Sacred History, and as one and the other treat of things so strange and incomprehensible to them, they do not advance a step in the language which it is intended to teach them. They recite or rather repeat a piece of sacred history or a prayer from the catechism that someone else reads aloud, without having the slightest idea of the words they use (Señoret, 1896, p. 34).
}

In the colonization process, there was also a "tuition" or adoption of Selk'nam children by the settler families. These children were taken by force from their communities and at other times they were taken voluntarily by their parents to the settlers' houses. There the children were taught western education, the language of the foreigners and household duties. About this 
Bascopé mentions that "it was the kidnapping and forced adoption of Fuegian children as a massive practice, motivated by the lack of servitude, which involved not only missionaries, but also spread among officials and businessmen" (Bascopé, 2011, p. 2; 2018).

This assimilation process culminated in a process of incorporation into the labor market on the ranches, as workers, transformed into laborers, cooks, nursemaids, gardeners, or domestic servants. In this way, the Selk'nam who remained in the areas now occupied by the settlers were transformed into rural semi-proletarians (Bartolome, 2003, p. 170), “civilized", assimilated and included in the tasks of the colonial enterprise. This is recounted by Manuel Señoret in his memoirs:

Such is what happened in Punta Arenas with the group of Indians brought last winter. Very soon after their arrival they visited the houses, split firewood, did a thousand domestic duties and learned the value of the currency. They returned daily to the same house and asked for remuneration for their work, with which they bought meat and other food to take to their families in the camp (Señoret, 1896, p. 32).

\section{The fall of the Selk'nam}

The process of colonization by private settlers in Tierra del Fuego, supported by the Chilean and Argentinean governments, resulted in the abrupt decrease of the Selk'nam population. This demographic collapse was due to the violent action of the colonizing companies, the introduction of various diseases in the territory as well as to the process of evangelization and forced assimilation. In 1919, Martín Gusinde -Priest and ethnologist dedicated to the study of the peoples of Tierra del Fuego- carried out a census, which estimated the Selk'nam population at 279 individuals. In 1928, the archaeologist and anthropologist Samuel Kirkland Lothrop, in his book "The Indians of Tierra del Fuego" (1928, p. 25) reported that the "pure-blooded" Selk'nam inhabitants of the island were extinct. In the same line, the researcher Anne Chapman, estimates that in 1966 there are only approximately 13 Selk'nam on the island (Chapman, 2008), and by 1973 she documents and reports on the death of Angela Loij, who was considered the last Selk'nam. The scientific discourse thus created the official extinction of the original inhabitants of the island.

Figure 1. Selknam population in Tierra del Fuego

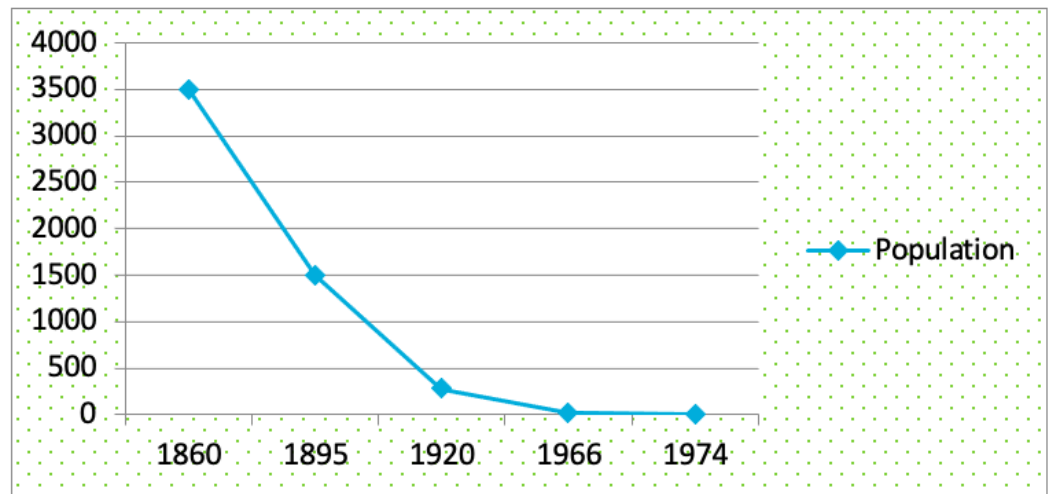

Source: Own elaboration 
Although the Selk'nam were victims of ethnocide, it is not correct to say that this process generated the extinction of the Selk'nam ethnic group and its culture. Rather, the Selknam were forced to live a process of violent cultural assimilation with modern society in Tierra del Fuego, where "they manifested a "syncretic" and "strategic" behavior, which allowed them, for example, to observe "territories", but also "lots"; to hunt, steal sheep, provide themselves in the estancia's storehouse or ask for help from the authorities; to live in camps, but also "houses"; to manipulate civilized materials in an "ethnic" way and vice versa" (Casali, 2017, p. 71). However, cultural presence, rituals, cosmovision, and traditions remain present and valid today, proving to be forms of survival and cultural resistance, overturning the biologically based extinction paradigm (Casali, 2017, p. 71).

More than the extinction of the Selk'nam, it was about making invisible the other, the strange, the Indian, that which did not fit with the idea of the unitary panorama of the State, it is for this reason that "the survivors, most of them women and girls, had to suffer the impossible to stop being what they were. And to become, among other things, Chilean and Argentine" (Alonso, 2019). In this way, they ceased to be "pure" indigenous under the logic of the time. Thus, racial and cultural stereotypes were the ones that established in the public and scientific discourse the disappearance or extinction of the Selk'nam, since under the different "civilizing mechanisms", they were assimilated to western life, they were considered from the legal perspective as Argentines or Chileans, they stopped dressing in their traditional guanaco capes, and they lived in houses and no longer in their tents. This meant for the paradigm of that time, that the Selk'nam were extinct and that they only existed in books, in the local folklore, in the archaeological pieces of the museums, making invisible those individual descendants who assumed and self-recognized themselves as Selk'nam.

The idea of the extinction of this indigenous group was also officially ratified by the State of Chile in 2003, when, through the Commission for Historical Truth and New Deal, it stated:

\footnotetext{
...in the last decades of the nineteenth century and the first decades of the twentieth century, the State's policy of concessions, the introduction of sheep in the southern steppes of the world, led to the physical elimination of [...] the totality of the Selk'nam (Presidential Commissioner for Indigenous Affairs 2008, p. 525).
}

However, in 1995, almost 20 years after the scientific discourse declared the extinction of the Selk'nam, a group of people began to organize, self-identifying themselves as belonging to the ethnic group. Thus, employing Resolution SdF No. 4070 of the National Institute of Indigenous Affairs, the Argentine state recognized the existence of the Community Selk'nam Rafaela Ishton, who were also awarded land in the Province of Tierra del Fuego. Similarly, in the 2010 Argentine National Census, 2,761 people recognized themselves as belonging to the Selk'nam culture.

The above points out that to consider the Selk'nam as an extinct indigenous people would be to resort to an essentialist and culturalist paradigm, centered on race as a category.

The resurgence of an ethnic group that was considered culturally extinct, would then be a process of ethnogenesis based on memory, oral tradition, and literature (Pérez, 2001), which has traditionally been understood as a process of configuration of ethnic groups or collectivities, as a result of specific historical processes. These configurations arise as a result of a process of differentiation (Bartolome, 2003, p. 174) from other groups through ethnic affiliation and selfrecognition (Brubaker \& Cooper, 2000). 


\section{On Ethnicity and Ethnogenesis}

Considering this context, it is now necessary to delve into the concepts of ethnicity and ethnogenesis, as categories that allow us to analyze the phenomenon of "resurgence" of the Selk'nam ethnic group. From Erving Goffman's perspective (1959), people are social subjects, who to generate their perception of themselves need the connection and intersection of different roles. These would be based on the social positions that each subject acquires in the social universe. In this sense Tiesler (2017, p. 33) points out that this unique combination of roles is what gives belonging to the subjects in society in general and in groups in particular, in this way, the different affiliations in groups give rise to the construction of personality in individuals.

In this context, it is necessary to point out that in the social science literature, the concept of "identity" has been used and exaggerated to explain the process of affiliation of individuals (Brubaker \& Cooper, 2000, p. 2; Gabbert, 2011; 2014; Quintana, 2016). This is because the concept is "too ambiguous, too divided between hard and soft meanings, essentialist connotations and constructivist qualifiers...Thus the use and abuse of "identity" affect not only the language of social analysis but inseparably its substance" (Brubaker \& Cooper, 2000, p. 2). Similarly, Detlev Clausen (2000) indicates that the concept "identity" concentrates on different analytical categories that are not well defined, transforming identity into a "verbal container". In other words, the concept of identity is used in a very general framework of meanings, without obtaining a clear and precise definition of it, which affects its use as an analytical category as such.

In the same direction, Nina Tiesler (2017, p. 37) remarks that identity applied to collectives is not an analytical category, therefore, the problematic character of the use of "identity" in these contexts is the reference to unique distinguishing characteristics and cultural traits that collectively constitute a broader reality with which it quickly identifies a person or group. This is because it would be a tautological justification for the explanation of group formations and affiliations, identity being an "abused" category in terms of its analytical and explanatory function. In this sense, the concept of ethnicity acquires a relevant meaning to explain self-definitions, ascriptions, ethnic framing, and ethnic resurgence. Thus, Mathias Bös (2010, p. 2) points out that to speak of human groups that define belonging based on their belief in common ancestry, the term ethnicity can be used.

In this sense, the concept of ethnicity is configured as an analytical category, which allows analyzing how individuals build processes of affiliation to ethnic groups, generating ethnic consciousness, with distinctive cultural elements, which allow the construction of ethnic boundaries (Barth, 1976), which remain persistent in terms of interaction with other groups as a process of constant differentiation. These ethnic borders can be understood as those symbolic cultural elements that shape the group, what Jenkins (1986, p. 184) called Symbolic Border Guards. It should also be noted that ethnic boundaries do not correspond to fixed and immutable elements but can change according to political, social, and historical contexts, allowing them to be manipulated, redrawn, erased, or consolidated (Stallaert, 1998, p. 13; Barth, 1976).

It is necessary to point out that following Wolfgang Gabbert's postulates (2011, p. 77; 2013, p. 3) we do not consider that ethnic groups correspond to natural and general forms of social organization; rather, their configuration is determined by historical processes, social and cultural changes, as well as a strong subjective element, where self-perceptions and forms of belonging play a relevant role in terms of social distinction. In this sense, ethnicity is configured as a central element in social change and transformation. 
We can then define ethnic groups as those human collectives that have a subjective belief in their common ancestry due to similarities in external habits, customs, memories of colonization, or migration. This belief must be relevant for the propagation of group formation; conversely, it does not matter whether or not there is an objective blood relationship (Tiesler, 2017, p. 11).

In this way, the advent of ethnicities is subject to the forms of symbolic distinction, to social and cultural changes, acquiring great relevance in those modern multicultural societies (Bös, 2015, p. 136), which adds to the postulates of Glazer and Moynihan (1995), who understand ethnicity as a modern ideology.

Ethnicity is then configured as a process of self-recognition and social differentiation of individuals through social groups, which take fragments of the past, chain them, build them, change their meaning or, if necessary, reinvent them (Gabbert, 2014, p. 197). These are modes of belonging, conceptual forms of self-perceptions of groups, the process by which individuals assume their ethnic belonging to the indigenous group, through the identification of their traits, specific cultural practices, their cosmovision, traditions, and beliefs.

How can an ethnic group that was extinct be present again? This question can be clarified by the emergence of ethnopolitical organizations, which contributed to recover the cultural and ethnic aspects of the Selk'nam, giving them a positive meaning, dignifying them, erasing the historical stigmatization of "being Indian", allowing the self-identification of individuals through ethnicity and memory, within specific historical, social and political contexts (Bartolome, 2003, p. 176). All this is linked to the concept of ethnogenesis, which is related to the historical process of reconfiguration of ethnic collectivities.

\section{From Ethnogenesis to Ethnoheterogenesis}

The concept of ethnogenesis has been used in the social sciences to explain how, through historical processes, ethnic collectivities take shape as a result of various social, political, and cultural factors.

In the work of Barbara Voss, The Archeology of Ethnogenesis (2008), an extensive review of the emergence and use of the concept is made, pointing out that Ethnogenesis refers to the birth of new cultural "identities". The moments of ethnogenesis point to the operation of historical and cultural changes that make previous types of identification less relevant, giving rise to new forms of self-recognition. Following this line, Tiesler, in his work Ethnoheterogenesis (2017, p. 17) refers to ethnogenesis as a determining concept to explain social change and ethnic change, in particular, understanding it not as a linear process of development and emergence of new ethnicities, but rather as a multidimensional and dynamic process.

Ethnogenesis is then a process of relevance and complexity in terms of the self-recognition and affiliation of individuals with ethnic groups, who self-recognize and frame themselves in an ethnic collective with shared characteristics. In this way, an ethnic designation emerges, culturally differentiated from the rest of society. In the Selk'nam case, this process of ethnogenesis occurs in the process of recovery of the common past, of the collective historicity, of traditions and ceremonies such as the initiation ceremony Hain- Where the youth of the community are encouraged and accepted as adult, incorporating them as full members of the group-, and the recognition of sacred places, through an ethno-community membership that allows the connection between the past and the present. 
The Selk'nam ethnogenesis process has been configured as a process of "resuscitating" (Pérez, 2001) an ethnic group that was considered extinct. This process of ethnogenesis has been reinforced through the work of ethnopolitical organizations, which have dedicated themselves to revaluing ethnic cultural aspects, giving significant emphasis to the rescue and teaching of the Selk'nam language, which was declared extinct in 1973 with the death of Angela Loij. Ethnopolitical organizations can be defined as those indigenous organizations that have focused on carrying out actions of a political orientation, focused on generating common demands, such as the recognition of their land rights, autonomy, the recognition of their language, as well as the defense of their territories.

An alternative to the concept of ethnogenesis is presented by Nina Tiesler (2017, p. 39), who proposes the concept of Ethnoheterogenesis (EHG), to remark that in the process of ethnogenesis and the formation of social entities in general, the forces of heterogenization and homogenization are present through a dialectic. Additionally, the EHG considers ethnicity as one of the many functions of belonging that individuals can acquire in different social contexts.

The concept of EHG acquires analytical relevance since it allows us to analyze from an ethnic perspective the different affiliations of individuals, groups, and macro groups in multicultural societies (Tiesler, 2017, p. 41).

Having said this, it is necessary to deepen a little more in the dialectical process previously mentioned. This Dialectic of hetero and homogenization considers that individuals, by generating processes of affiliation to ethnic groups, through their subjective experiences and preferences, generate a process of homogenization and self-identification with the group, where they share functional qualities concerning their belonging. At the same time, a process of heterogenization is generated, where through ethnic boundaries, they differentiate themselves from the rest of society and the rest of the other ethnic groups. Generating in this way a double process of belonging and self-recognition as well as differentiation.

Below is an illustration in which the dialectical process of Ethnoheterogenesis can be seen more clearly (Figure 2).

Figure 2. Ethnoheterogenesis

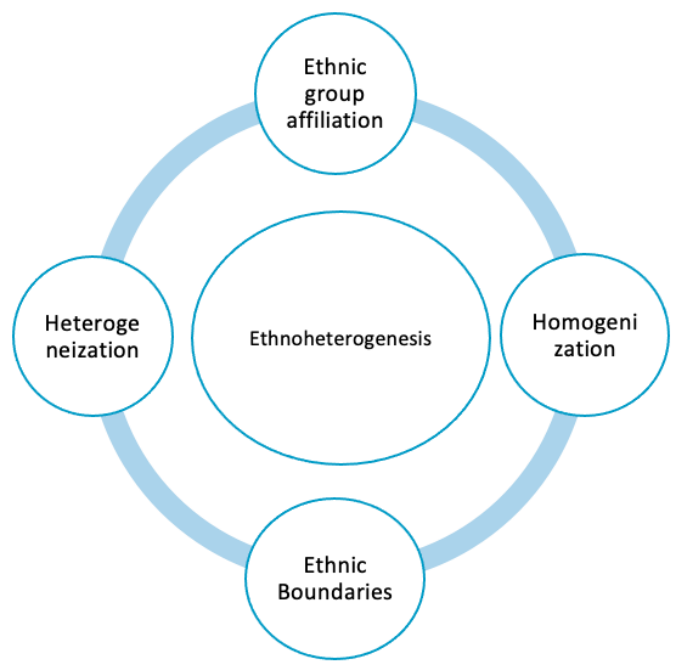

Source: Own elaboration 
In the figure we can identify the four elements that give form to the process of Ethnoheterogenesis. Even though it is a dialectical-circular process, first of all, we can see that the subjects begin with a process of 1) ethnic affiliation with a group, this affiliation is based on sharing cultural elements, such as language, their cosmovision, their religiosity, among others, recognizing themselves with the group; This allows the 2) homogenization of the group based on the values and cultural elements shared by its members, through this homogenization also generates 3 ) ethnic boundaries in relation to other ethnic groups and with the rest of society, to generate in this way a practical and symbolic differentiation; this differentiation generates 4 ) the heterogenization of the group with the rest of society, ultimately allowing a strengthening of the group and its members. Completing in this way the EHG process.

\section{The resurgence of the Selk'nam ethnicity in Tierra del Fuego.}

As already mentioned, since 1995, with the recognition by the Argentine government of the Selk'nam Rafaela Ishton Indigenous Community, there has been a strong process of ethnicity in Tierra del Fuego. At present, this community has a strong cultural impact in the region, grouping more than 450 people who recognize themselves as Selk'nam, based on historical memory, family stories, and the preservation of their traditions (Bartolome, 2003, p. 178). Thus, through this community, the survival of the Selk'nam has been affirmed, which led to in Argentina a process of territorial restitution to families who recognized themselves as Selk'nam, which resulted in the delivery in 2000 of more than 36,000 hectares of territory recognized as ancestral and since 2011 they have legal status and title of community land ownership (Rodríguez \& Horlent, 2016). In the same way, important ceremonial sites have been recognized, such as the Taps Lake, where the ancient Kloketen ceremony took place (Bartolome, 2003, p. 13), which has been re-signified and its dissemination has been expanded and is currently carried out by some families.

In the 2010 National Census of Argentina, 3,563 people reported self-identification and selfrecognition as indigenous Selk'nam (Rodríguez \& Horlent, 2016, p. 36). This speaks to us of a process of ethnicity, resistant to time and scientific history, for more than 20 years, where individuals recognize their ethnic affiliation with the Selk'nam (Méndez, 2012a, p. 6; 2012b), based on cultural, structural, and significant elements that allow them to build community-based on ethnicity, contracting the official historical perspective where they were declared extinct.

In this way, Selk'nam ethnicity and its cultural phenomena remain persistent. In the words of Anthony Smith (1988), this is a process of long-term ethnic survival, where symbols, myths, memories, traditions, rituals and language persist despite social changes and the passage of time (Stallaert, 1998).

Thus, the process of Ethnoheterogenesis should be understood as a paradigm shift, leaving aside the perspective that considered indigenous groups as racially "pure". This is also pointed out by a person who self-identifies as Selk'nam:

However, we have engraved in our minds the stereotype spread by the white colonizers who saw the 'agony' of our people, that is the fact of speaking of the last of such tribe, because in this way we put an end to this people, excluding the mestizo descendants that arise from that one. It is what happens with me, in my life, I have treated myself as the last Selk'nam, because if I did it I would be excluding all the people that I named and that evidently I recognize as such. That is the mistake that 
the journalists who interview me tend to make, who have engraved that stereotype of which I spoke (Yanten, 2007).

Regarding this process on the Chilean side of the island, the recognition of the Selk'nam has been dealt with much more slowly by the State institutions. However, the people who self-recognize their Selk'nam ethnicity have organized themselves in the Covadonga Ona Community, which groups more than 200 people. Thus, in the last census conducted in Chile (2017), 28,115 people self-recognized as belonging to indigenous communities not recognized by the State. Of these 28,115 people, 1,444 self-recognized as Selk’nam (Meza-Lopehandia \& Rivera, 2020).

It is necessary to mention that the Chilean State, by means of the Indigenous Law of 1993, does not recognize the Selk'nam as a living indigenous ethnic group in Chile. For this reason, the Covandonga Ona Community has promoted the initiative to achieve recognition by the State of their existence as a living ethnic group based on,

...the elements that make up an experience shared by the relatives of the survivors, which beyond biological descent-whether as a phenotypic or genetic trace-allows the reconstruction of a cultural identity from fragments and a will of memory to persist (Meza-Lopehandia \& Rivera, 2020, p. 8).

In this sense, Chilean law establishes objective criteria for collective recognition: 1) descent from pre-Columbian groups; 2) cultural continuity, and 3) identity relationship with the land. Based on these criteria, the Covandonga Ona Community's claim would be valid and meet the legally imposed conditions.

\section{Conclusions}

To conclude, we can point out that the Selk'nam, original inhabitants of Tierra del Fuego Island, faced different processes for which they were considered extinct. These processes are 1) Colonization and militarization of the Territory; 2) Evangelization; 3) Incorporation into the labor market in the haciendas; 4) Assimilation; 5) Essentialist Scientific Paradigm.

The sum of all these processes generated that from the institutionalism, the genocide and extinction of the Selk'nam was declared. However, through the various processes of ethnicity and from a new paradigm in anthropology, we can point out that such extinction is not effective, since it would rather be a process of concealment of ethnicity, which is due to various causes such as forced cultural assimilation, fear of discrimination among other aspects.

The perspective of ethnicity and ethnoheterogenesis has allowed us to analyze that social groups and minorities are not homogeneous units, and that self-recognition and the process of membership is a historical and dynamic process, influenced by national contexts; in this sense, the dialectic of hetero- and homogenization acquires meaning in the process of recognition of ethnic membership. In this way, the Selk'nam cultural persistence and the self-recognition of individuals as members of the indigenous group, through the process of identification of their culture, their traditions, their language, has generated a process in which the Argentine State has had to recognize the Selk'nam Rafaela Ishton Indigenous Community as a living indigenous group.

In the same way, this process has influenced ethno-political organizations in Chile to organize themselves to seek recognition of the Selk'nam as a living ethnic group. This recognition would 
not only be symbolic and reparatory in terms of their historical significance but would also allow for the recognition of territorial rights, the recognition of indigenous authorities, and the enforcement of international instruments such as ILO Convention 169.

In this sense, the current process of building a new constitution in Chile has created spaces in which indigenous groups have been actively present, acquiring special quotas in the constitutional space, which means an important space of influence in the construction of the new constitution and in the future of the country. In this context, new questions arise as to how indigenous groups could influence the construction of a new post-colonial, democratic and inclusive constitution, which would allow the creation of a plurinational state respectful of those indigenous groups that have been made invisible and forgotten in history, such as the Selk 'nam.

In this way, we can demonstrate the importance that the application of analytical concepts such as ethnoheterogenesis acquires for the study of indigenous groups, since it allows to analyze the processes of re-significance, membership, differentiation of indigenous groups, permitting to know the way in which they strengthen their culture. This makes it possible to position them in current spaces and the various roles in which they acquire influence, as for example in the case of Chile in national politics. In this sense, concepts such as ethoheterogenesis would come to justify from a scientific perspective the emergence of indigenous groups based on ethnicity and not on essentialist categories such as race, permitting the analysis from a more dynamic perspective the postcolonial societies and their heterogeneity, and also serving as a tool to support historical claims of historically marginalized groups.

The example of the Selk' nam has shown that indigenous groups are in constant change, that is, through political and cultural processes they are in active processes of reaffirmation of their culture and ethnicity, seeking legal recognition as distinct groups and ultimately the recognition of collective rights that are favorable to them. The Selk'nam case, on the other hand, is another case in which indigenous groups in the Americas have been victims of colonialism, being forced to assimilate into the dominant society. However, in the current context, we can find several examples in which indigenous groups strive to fight for their recognition as a way of de-colonizing the State, which will ultimately allow for the expansion of democracies and the inclusion of historically excluded groups in Latin America.

Finally, this process of re-ethnification also means a recognition of the pluriculturality present in Chile as well as in Argentina and a recognition of the heterogeneity of ethnic groups in Latin America.

\section{REFERENCES}

Albiez, S., Castro, N., Jüssen, L \& Youkhana, E. (Eds.) (2011). Etnicidad, ciudadanía y pertenencia. Prácticas, teoría y dimensiones espaciales. Iberoamericana Vervuert Verlagsgesellschaft.

Alonso Marchante, J. (2019). Selk'nam. Genocidio y resistencia. Catalonia.

Barth, F. (1976). Los grupos étnicos y sus fronteras. La organización social de las diferencias culturales. Fondo de Cultura Económica.

Bartolomé, M. A. (2003): Los pobladores del “Desierto”, genocidio, etnocidio y etnogénesis en la Argentina. Cuadernos de Antropología Social (17), 162-189. https://doi.org/10.34096/cas.i17.4604

Bascopé, J. (2011). Bajo tuición. Infancia y extinción en la historia de la colonización fueguina. Archivos virtuales de la alteridad Americana, 1-24. https://doi.org/10.4000/corpusarchivos.975 
Bascopé, J. (2018). En un área de tránsito polar: desde el establecimiento de líneas regulares de vapores por el estrecho de Magallanes (1872) hasta la apertura del canal de Panamá (1914). Ediciones Co Libris.

Boccara, G. (1999). Etnogénesis mapuche: resistencia y restructuración entre los indígenas del cetro-sur de Chile (Siglos XVI-XVIII). Hispanic American Historical Review, 425-461.

Bös, M. (2010). Race and Ethnicity: The History of Two Concepts in American Sociology. Sociology of Citizenship: 105th American Sociological Association Annual Meeting, Section on History of Sociology. American Sociological Association. Atlanta.

Bös, M. (2015). Ethnicity and Ethnic Groups: Historical Aspects. In J. Wright (Ed.), International Encyclopedia of the Social \& Behavioral Sciences, 2 ed. (pp. 136-141). Elsevier.

Brubaker, R., Cooper, F. (2000). Beyond "Identity". Theory and Society, 29(1), 1-47. https://doi.org/ 10.1023/A:1007068714468.

Casali, R. (2017). De la extinción al genocidio Selk’nam: sobre Historia e historias para una expiación intelectual. Tierra del Fuego, Argentina. A contra corriente, 15(1), 60-78.

Chapman, A. (1973). Angela Loij, la última selk’nam. Journal de la société des américanistes, 62(1), 232-234. https://www.persee.fr/doc/jsa_0037-9174_1973_num_62_1_3003

Chapman, A. (2008). End of a world. The Selknam of Tierra del Fuego. 1st ed. Zagier \& Urruty Publicaciones.

Claussen, D. (2000). Aspekte der Alltagsreligion. Ideologiekritik unter veränderten gesellschaftlichen Verhältnissen. Verlag Neue Kritik (Hannoversche Schriften, 3).

Comisionado presidencial para asuntos indígenas (2008). Informe de la Comisión Verdad Histórica y Nuevo Trato con los Pueblos Indígenas. Ediciones Pehuén. Biblioteca del Bicentenario.

Coronato, F. (2010). El rol de la ganadería ovina en la construcción del territorio de la Patagonia. Institut des Sciences et Industries du Vivant et de I'Environnement.

Gabbert, W. (2007). In the Shadow of the Empire - The Emergence of Afro-Creole Societies in Belize and Nicaragua. Indiana, 39-66. https://doi.org/10.18441/ind.v24io.39-66

Gabbert, W. (2011). Shifting Boundaries, Emerging Communities -Ethnicity and Ethnogenesis on Nicaragua's Atlantic Coast. In S. Albiez, N. Castro, L. Jüssen \& E. Youkhana (Eds.), Etnicidad, ciudadanía y pertenencia. Prácticas, teoríay dimensiones espaciales. (pp. 65-92). Vervuert Verlagsgesellschaft.

Gabbert,W. (2013). Cultura, Cambio Social y Estado. Dinámicas de Etnogénesis y Movilización. Kompetenznetz Lateinamerika (3), 1-22.

Gabbert,W. (2014). Ethnicity and Social Change:Miskitus Ethno-Genesis in Eastern Nicaragua. In J. Raab(Ed.), New world colors. Ethnicity, belonging, and difference in the Americas (pp. 193-208). Wissenschaftlicher Verlag Trier copublished by Bilingual Press (Inter-American studies Estudios interamericanos, volume 9).

Glazer, N., \& Moynihan, D. (eds.) (1995). Ethnicity. Theory and experience. Harvard Univ. Press.

Goffman, E. (1959). The Presentation of Self in Everyday Life. Doubleday.

Gusinde, M. (1920a). Expedición a la tierra del Fuego. Publicaciones del Museo de Etnología y Antropología de Chile 2(1), 9-44.

Gusinde, M. (1920b). Segundo viaje a la Tierra del Fuego. Publicaciones del Museo de Etnología y Antropología de Chile 2(2), 133-163.

Gusinde, M. (1922). Tercer viaje a Tierra del Fuego. Publicaciones del Museo de Etnología y Antropología de Chile 2(3), 417-436.

Gusinde, M. (1924). Cuarta Expedición a la Tierra del Fuego. Publicaciones del Museo de Etnología y Antropología de Chile 4(1), 7-67. 
Gusinde, M. (1951). Hombres Primitivos en la Tierra del Fuego. De investigador a compañero de tribu. Escuela de Estudios Hispano-Americanos.

Gusinde, M. (1982). Los Indios de Tierra del Fuego. Los Selk’nam. Centro Argentino de Etnología Americana.

Harambour, A. (2016). Sheep Sovereignties: The Colonization of the Falkland Island/Malvinas, Patagonia and Tierra del Fuego, 1830-1910. Oxford Research Encyclopedia of Latin American History, 1-23.

Instituto de Estudios Indígenas (2003). Los derechos de los pueblos indígenas en Chile. Informe del Programa de Derechos Humanos. LOM Ed.

Jenkins, R. (1986). Social Anthropological Models of Inter-Ethnic Relations. In: D. Mason and J. Rex (Eds.): Theories of race and ethnic relations. Cambridge University Press (Comparative ethnic and race relations).

Quintana, L. (2016). Enfoques y criticas del concepto de identidad. PODIUM, 43-60.

Lorandi, A., \& Rio, M. (1992). La etnohistoria: etnogénesis y transformaciones sociales andinas. Centro Editor de America Latina.

Lothrop, S. K. (1928). The Indians of Tierra del Fuego. Museum of the American Indian.

Luna, G. (2014). Trayectoria critica del concepto de etnogénesis. Logos: Revista de Lingüística, Filosofía y Literatura, 167-179. https://doi.org/10.15443/RL2414

Mantel, M. (2017). Etnogénesis, relatos de origen, etnicidad e identidad étnica: en torno a los conceptos y sus definiciones. Anales de Historia Antigua, Medieval y Moderna, 71-86. https://doi.org/10.34096/ ahamm.v51.4303

Massone, M., Jackson, D., \& Prieto, A (1993). Perspectivas arqueológicas de los Selk'nam. Dirección de Bibliotecas, Archivos y Museos.

Méndez, P. (2012a). La extinción de los selknam (onas) de la isla de Tierra del Fuego. Ciencia, discurso y orden social. Gazeta de Antropología 28 (2), 1-14. https://digibug.ugr.es/handle/10481/22063

Méndez, P. (2012b). Diezmados por la colonización y extinguidos por la ciencia. Los Selk'nam (Onas) de la Isla de Tierra del Fuego. Editorial Académica Española.

Meza-Lopehandia, M., \& Rivera, F. (2020). Reconocimiento del Pueblo Selk'nam. Biblioteca del Congreso Nacional de Chile.

Ministerio de Educación de la Nación (2016). Pueblos Indígenas en la Argentina: historias, culturales, lenguas y educación. Ministerio de Educación de la Nación.

Pérez, A. (2001): De la etnoescatología a la etnogénesis. Notas sobre las nuevas identidades étnicas. Revista de Antropología Experimental 1, 1-12.

Rodríguez, M., \& Horlent, L. (2016). Tehuelches y Selk'nam. No desaparecimos. In: S. Hirsch y A. Lazzari (Eds.), Pueblos Indígenas en la Argentina: historias, culturales, lenguas y educación, 7-38. Ministerio de Educación de la Nación.

Señoret, M. (1896). Memoria del Gobernador de Magallanes. La tierra del fuego i sus naturales. Imprenta Nacional.

Smith, A. D. (1988). The Ethnic origins of nations. B. Blackwell.

Stallaert, C. (1998). Etnogénesis y etnicidad en España. Una aproximación histórico-antropológica al casticismo. $1^{\text {a }}$ ed. corr. y aum. Proyecto A.

Tiesler, N. (2017). Ethnoheterogenesis. The dialectics of hetero and homogenization in processes of ethnic framing and membership. ISH. 
Voss, B. (2008). The Archaeology of Ethnogenesis. Race, Sexuality, and Identity in Colonial San Francisco. University of California Press.

Yanten, J. (2007). Los Selk’nam estamos de pie. edit. Blogspot. http://joubert-yanten.blogspot.com/

\section{AUTHOR}

Javier Lastra-Bravo. Ph.D. Candidate in Sociology and Cultural Anthropology at Leibniz Universitat Hannover, Germany. Professor and researcher at the institute for sociology of the Gottfried Wilhelm Leibniz University of Hannover, in the fields of Sociology and Atlantic Studies.

\section{Conflict of interest}

No potential conflict of interest is reported by the authors.

\section{Funding}

No financial assistance from parties outside this article.

\section{Acknowledgments}

$\mathrm{N} / \mathrm{A}$ 